\title{
EFFECT OF AZOTOBACTER ON GROWTH AND YIELD OF MAIZE
}

\author{
Bandhu Raj Baral ${ }^{*}$ and Parbati Adhikari \\ Nepal Agricultural Research Council, National Maize Research Program, Rampur, Chitwan, Nepal
}

\begin{abstract}
A field experiment was conducted to study the effect of Azotobacter on growth and yield of maize (variety Rampur composite) at farmland of National Maize Research Program, Rampur, Chitwan, Nepal during the winter season of 2007-08 and 2008-09. The experiment was laid out in randomized complete block design with eight treatments each replicated three times. The treatments were control, 120:60:40 kg NP${ }_{2} \mathrm{O}_{5} \mathrm{~K}_{2} \mathrm{O} \mathrm{ha}^{-1}$, Azotobacter seed inoculation, Azotobacter soil application, Azotobacter +10 t FYM ha ${ }^{-1}, 10$ t FYM ha ${ }^{-1}, 120: 60: 40 \mathrm{~kg} \mathrm{NP}_{2} \mathrm{O}_{5} \mathrm{~K}_{2} \mathrm{O} \mathrm{ha}^{-1}+$

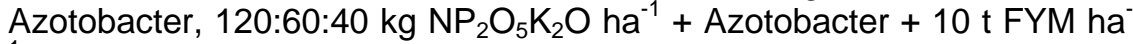
1 . Analysis of variance showed that grain yield, plant height, ear height, ear length, kernel per rows and 1000 grain weight were significantly affected with treatments. Only inoculation of Azotobacter increased 15 to $35 \%$ grain yield over non inoculated treatments. The benefit of Azotobacter inoculation was higher in the absence of chemical fertilizer application.
\end{abstract}

Key words: Azotobacter, chemical fertilizer, FYM, grain yield, seed inoculation

\section{INTRODUCTION}

The worldwide spread of inflation, initiated by several fold rises in Petroleum price thereby depicting its striking influence on the prices of chemical nitrogenous fertilizers. The prices of nitrogenous fertilizers have nearly doubled during the last 34 years. This has necessitated searching for cheaper source of nitrogen to meet the needs of crops. Farmers use chemical fertilizers to increase production to meet their needs, but the excessive use of fertilizers leads to contamination of soil and groundwater and reduce soil fertility. On the other hand, for marginal farmers in Nepal, the purchase of chemical fertilizers is difficult and expensive. So, biofertilizers can replace partially chemical fertilizers. Hence, there is a need to

**Corresponding author email: bandhu.baral@gmail.com

Received: 14.05.2013 
search for alternative strategies to improve soil health without causing damage to environment as well as soil. Therefore, biofertilizers are gaining importance as they are ecofriendly, non hazardous and nontoxic products (Sharma et al., 2007).

Biofertilizers include mainly the nitrogen fixing, phosphate solubilizing and plant growth promoting microorganisms. Biofertilizers benefiting the crop production are Azotobacter, Azospirillum, blue green algae, Azolla, P-solubilizing microorganisms, mycorrhizae and sinorhizobium (Selvakumar et al, 2009). Among the biofertilizers,. Azotobacter represents the main group of heterotrophic, non symbiotic, gram negative, free living nitrogen-fixing bacteria. They are capable of fixing an average $20 \mathrm{~kg}$ N/ha/year. The genus Azotobacter includes 6 species, with $A$. chroococcum most commonly inhabiting in various soils all over the world (Mahato et al., 2009). Besides nitrogen fixation, Azotobacter also produces thiamin, riboflavin, indole acetic acid and gibberellins. When Azotobacter is applied to seeds, seed germination is improved to a considerable extent, so also it controls plant diseases due to above substances produced by Azotobacter. The exact mode of action by which Azotobacteria enhances plant growth is not yet fully understood. Three possible mechanisms have been proposed: $\mathrm{N}_{2}$ fixation; delivering combined nitrogen to the plant; the production of phytohormone-like substances that alter plant growth and morphology, and bacterial nitrate reduction, which increases nitrogen accumulation in inoculated plants (Mrkovacki and and Milic, 2001). In Nepal very limited studies were carried out on the effect of Azotobacter on maize growth and productivity. Therefore, a field experiment was carried out to study the effect of Azotobacter on maize growth and productivity.

\section{MATERIALS AND METHODS}

The experiment was conducted at farm land of National Maize Research Program, Rampur, Chitwan, Nepal. The experiment was carried out during the winter season of 2007-08 and 2008-09. The treatment consist of $\mathrm{T}_{1}=$ Control, $\mathrm{T}_{2}=$ Recommended dose of chemical fertilizer (RDF; 120:60:40 kg NP${ }_{2} \mathrm{O}_{5} \mathrm{~K}_{2} \mathrm{O}$ ha $^{-1}$ ), $\mathrm{T}_{3}=$ Azotobacter seed inoculation, $\mathrm{T}_{4}=$ Azotobacter soil inoculation, $\mathrm{T}_{5}=$ Azotobacter + 10 t FYM ha ${ }^{-1}, \mathrm{~T}_{6}=10$ t FYM ha $^{-1}, \mathrm{~T}_{7}=\mathrm{RDF}\left(120: 60: 40 \mathrm{~kg} \mathrm{NP}_{2} \mathrm{O}_{5} \mathrm{~K}_{2} \mathrm{O} \mathrm{ha}^{-1}\right)+$ Azotobacter, $\mathrm{T}_{8}=\mathrm{RDF}\left(120: 60: 40 \mathrm{~kg} \mathrm{NP}_{2} \mathrm{O}_{5} \mathrm{~K}_{2} \mathrm{O}\right.$ ha $\left.^{-1}\right)+$ Azotobacter +10 t FYM

$\mathrm{ha}^{-1}$. The experiment was laid out in randomized complete block design (RCBD) with three replications. Maize open pollinated variety named Rampur composite was planted in $12 \mathrm{~m}^{-2}$ plot with the row to row spacing $75 \mathrm{~cm}$ and $25 \mathrm{~cm}$ plant to plant spacing. The sources of chemical fertilizer were Urea, DAP and MOP. Seed inoculation with the Azotobacter was carried out by using 10\% sugar solution carrier. The sugar solution was prepared by adding $100 \mathrm{~g}$ sugar in 1 litre water and boiled then. After cooling the solution, maize seeds were put in the solution pot and taken out and the inoculants were thoroughly mixed with the maize seeds. These seeds were kept in shade before planting. The inoculation was done just few hours before seed sowing. Soil sampling was done before sowing and analyzed for total N, 
available $\mathrm{P}$, available $\mathrm{K}$, Organic matter and $\mathrm{pH}$. The soil was alluvial sandy loam in texture. The initial total $\mathrm{N}$ content was low $(0.05 \%)$, available $\mathrm{P}_{2} \mathrm{O}_{5}$ was high $(173 \mathrm{~kg}$

$\left.\mathrm{ha}^{-1}\right)$, available $\mathrm{K}_{2} \mathrm{O}$ was medium $\left(102 \mathrm{~kg} \mathrm{ha}^{-1}\right)$, organic matter was low (2.12\%) and medium acidic in $\mathrm{pH}$ (6.0). All the intercultural operation were carried out as per need. ANOVA was carried out using Genstat 13.2. The significant differences among the means were tested using least significance difference (LSD) at $5 \%$ significance level.

\section{RESULTS AND DISCUSSION}

\section{Growth and harvested ear}

Inoculation with Azotobacter significantly influenced the plant and ear height of maize during 2007-08 and 2008-09 (Table 1). Two years mean revealed that maximum plant height (120.5) was recorded with the application of recommended dose of chemical fertilizer plus $10 \mathrm{t} \mathrm{FYM} \mathrm{ha}^{-1}$ and Azotobacter inoculation. During 2008-09 the overall plants were taller as compared to 2007-08. Similarly, the ear placement height showed similar trend as like plant height. The numbers of harvested ears per $\mathrm{m}^{2}$ were significantly affected. The highest number of ears per $\mathrm{m}^{2}(5.41)$ was recorded in the treatment applied with recommended dose of chemical fertilizer along with Azotobacter inoculation and $10 \mathrm{t} \mathrm{FYM} \mathrm{ha}^{-1}$. It seems that chemical combination of organic and inorganic fertilizer increase the number of ear per $\mathrm{m}^{2}$. The numbers of unfilled ears per $\mathrm{m}^{2}$ was not influenced by the Azotobacter inoculation and other treatments in compared to control during both years.

\section{Yield attributes}

Yield parameters specially ear length, kernels per rows and 1000 grains weight. were highly influenced by Azotobacter inoculation. The mean ear length varied form $10.4 \mathrm{~cm}$ to $14.1 \mathrm{~cm}$ (Table 2). The maximum ear length (14.1) was seen in the treatment combination consisting of Azotobacter inoculation along with recommended dose of chemical fertilizer and $10 \mathrm{t} \mathrm{FYM} \mathrm{ha}^{-1}$. In contrast, the minimum ear length (10.4) was seen in control. The number of kernel rows per ear was not affected by the treatment during both years. The numbers of kernels per row was significantly influenced by Azotobacter inoculation in 2007-08. However, in 2008-09 kernels per row were not affected by treatments. In 2007-08, maximum number of kernels per rows was obtained in the treatment consisting of Azotobacter inoculation along with recommended dose of chemical fertilizer and $10 \mathrm{t} \mathrm{FYM} \mathrm{ha} \mathrm{F}^{-1}$. From this result, it was confirmed that the effect of Azotobacter, chemical fertilizer and FYM were positive and additive on numbers of kernel setting per ear. Thousand grains weight was significantly influenced by the treatment in both the years. Two years mean 1000 grain weight was varied from 432 to 490.8 g. The highest 1000 grains weight was measured in the treatment inoculated with Azotobacter along with recommended dose of chemical fertilizer and $10 \mathrm{t} \mathrm{FYM} \mathrm{ha}^{-1}$ and lowest 1000 grains weight. was measured in the treatment of $10 \mathrm{t} \mathrm{FYM} \mathrm{ha}^{-1}$ applied. Kader et al, (2002) 
reported that Azotobacter increases $\mathrm{N}$ availability in the soil which could enhance the numbers of grains and 1000 grains weight Application of recommended dose of chemical fertilizer showed major influencing factor in 1000 grain weight in 2007-08. The variation of influence of Azotobacter on yield attributes such as 1000 grains weight in 2008-09 than previous year may be the Azotobacter sp. populations affected by soil chemical (e.g. organic matter, pH, temperature, soil depth, soil moisture) and microbiological (e.g. microbial interactions) properties (Ridvan, 2009).

\section{Grain and stover yield}

Grain and stover yield were significantly influenced by the Azotobacter inoculation during both years. The grain yield varied from $2.83 \mathrm{tha}^{-1}$ to $6.62 \mathrm{t} \mathrm{ha}^{-1}$ (Table 3). The highest grain yield $\left(6.42 \mathrm{t} \mathrm{ha}^{-1}\right)$ was recorded with the Azotobacter inoculation along with recommended dose of chemical fertilizer and $10 \mathrm{t} \mathrm{FYM} \mathrm{ha}^{-1}$ treatment. In contrast the lowest grain yield $\left(2.83 \mathrm{t} \mathrm{ha}^{-1}\right)$ was recorded in control. Two years mean grain yield revealed that only inoculation of Azotobacter increased grain yield 0.3 to $35 \%$ more as compared to non inoculated treatment combination. Similarly, the highest stover yield (11.9 $\left.\mathrm{t} \mathrm{ha}^{-1}\right)$ and lowest stover yield (3.83 $\left.\mathrm{t} \mathrm{ha}^{-1}\right)$ were seen with the same treatments which produced highest grain yield and lowest grain yield. Peng et al. (2013) also reported the positive effect of manure and Azotobacter application on maize biomass. The stover and grain yield were highly correlated in the experiment (not shown). The highest benefit of 35\% grain yield increment was obtained with the seed inoculation treatment over the control followed by $34 \%$ in soil inoculated treatment over the control treatment. Inoculation of Azotobacter in addition to only $10 \mathrm{t} \mathrm{FYM} \mathrm{ha}^{-1}$ increased $15 \%$ more grain yield over the treatment only applied 10 t FYM ha ${ }^{-1}$. The lowest benefit of $0.3 \%$ increase in yield by Azotobacter inoculation was obtained in the treatment applied with recommended dose of chemical fertilizer and Azotobacter inoculation over the recommended chemical fertilizer applied treatment. This result was in line with the Peng et al. (2013), they concluded that Azotobacter chroococcum inoculation with maize seeds not only economically most efficient at lower doses of $\mathrm{N}$ but also saved $\mathrm{N}$ when applied in combination with FYM. Biari et al. (2008) also found positive effect of Azotobacter application on maize grain yield increase at organic field condition. The benefit of Azotobacter applying with FYM could be as Azotobacter uses carbon for its metabolism from simple or compound substances of carbonaceous in nature. Besides carbon, Azotobacter also requires calcium for nitrogen fixation. Similarly, a medium used for growth of Azotobacter is required to have presence of organic nitrogen, micro-nutrients and salt in order to enhance the nitrogen fixing ability of Azotobacter. 


\section{CONCLUSION}

Inoculation with Azotobacter significantly increased plant height, ear height, number of ears per $\mathrm{m}^{2}$, ear length, kernel per row, 1000 grain weight, grain and stover yield of maize. Only inoculation of Azotobacter increased maize grain yield upto 35\% over non inoculated treatment. The benefit of Azotobacter inoculation was higher when chemical fertilizer was not used. A positive additive (15\% yield increased) effect of $10 \mathrm{t} \mathrm{FYM} \mathrm{ha}^{-1}$ with Azotobacter inoculation was seen. Therefore, it was concluded that Azotobacter could be one of the biofertilizer option for sustainable and environmental ecofriendly for maize production where chemical fertilizer is limited.

\section{ACKNOWLEDGEMENT}

The authors would like to thank the Executive Director of Nepal Agricultural Research Council (NARC) Dr. D. B. Gurung (former Maize Coordinator) for providing support to conduct this experiment and Dr. K. B. Koirala Maize Coordinator who motivated to write the paper. The authors would also like to thank H. L. Bohora for his continuous help during field and lab work of this experiment.

\section{REFERENCES}

Biari, A., Gholami, A. and Rahmani, H. A. 2008. Growth promotion and enhanced nutrient uptake of maize (Zea mays L.) by application of plant growth promoting rhizobacteria in Arid region of Iran. Journal of Biological Sciences, 8: 1015-1020

Kader, M. A., Mian, M. H. and Hoque, M. S. 2002. Effect of Azotobacter inoculants on the yield and nitrogen uptake by wheat. Journal of Biological science, 4: 259-261

Ridvan K. 2009. Nitrogen fixation capacity of Azotobacter spp. Strains isolated from soils in different ecosystems and relationship between them and the microbiological properties of soils. Journal of Environmental Biology, 30 (1):73-82

Mahato P., Badoni, A. and. Chauhan, J. S. 2009. Effect of Azotobacter and Nitrogen on Seed Germination and Early Seedling Growth in Tomato. Researcher, 1(4):62-66

Mrkovacki, N., Milic, V. 2001. Use of Azotobacter chroococcum as potentially useful in agricultural application. Annals of Microbiology, 51:145-158

Peng, S. H., Wan-Azha, W. M., Wong, W. Z. Go, W. Z., Chai, E. W., Chin, K. L. and H`ng, P. S. 2013. Effect of Using Agro-fertilizers and N-fixing Azotobacter Enhanced Biofertilizers on the Growth and Yield of Corn. Journal of Applied Sciences, 13: 508512

Selvakumar, G., Lenin, M., Thamizhiniyan, P. and Ravimycin,T. 2009. Response of biofertilizers on the growth and yield of blackgram (Vigna mungo L.). Recent Research in Science and Technology, 1(4):169-175

Sharma K., Dak G., Agrawal A., Bhatnagar M. and Sharma R. 2007. Effect of phosphate solubilizing bacteria on the germination of Cicer arietinum seeds and seedling growth. Journal of Herbal Medicine and Toxicology, 1(1):61-63 
Table 1: Effects of Azotobacter on growth and yield attributes of maize during 2007-08 and 2008-09 at Rampur

\begin{tabular}{|c|c|c|c|c|c|c|c|c|c|c|c|c|}
\hline \multirow{2}{*}{ Treatments } & \multicolumn{3}{|c|}{ Plant height (cm) } & \multicolumn{3}{|c|}{ Ear height $(\mathrm{cm})$} & \multicolumn{3}{|c|}{ Harvested ears/m ${ }^{2}$} & \multicolumn{3}{|c|}{ Unfilled ear $/ \mathrm{m}^{2}$} \\
\hline & 2007-08 & 2008-09 & Mean & 2007-08 & 2008-09 & Mean & 2007- 08 & 2008-09 & Mean & 2007-08 & 2008-09 & Mean \\
\hline $\mathrm{T} 2$ & 194 & 213 & 203.5 & 85 & 112 & 98.5 & 5.56 & 5.05 & 5.30 & 0.20 & 0.50 & 0.35 \\
\hline T4 & 184 & 209 & 196.5 & 68 & 108 & 88.0 & 4.13 & 4.66 & 4.39 & 1.35 & 0.83 & 1.09 \\
\hline T5 & 188 & 211 & 199.5 & 90 & 113 & 101.5 & 4.33 & 4.00 & 4.16 & 0.96 & 1.38 & 1.17 \\
\hline T6 & 186 & 214 & 200.0 & 96 & 111 & 103.5 & 5.08 & 4.60 & 4.84 & 0.33 & 0.93 & 0.63 \\
\hline F-test & $* *$ & $* *$ & & * & $* *$ & & * & * & & NS & NS & \\
\hline $\mathrm{CV} \%$ & 5.2 & 2.92 & & 9.5 & 4.95 & & 14.2 & 10.3 & & 24.7 & 28.80 & \\
\hline $\operatorname{LSD}(0.05)$ & 13.6 & 10.7 & & 14.3 & 9.51 & & 1.00 & 0.84 & & & - & \\
\hline
\end{tabular}

NS, $p>0.05 ; *$, p $<0.05 ; * *, p>0.01$

Table 2: Effects of Azotobacter on yield attributes of maize during 2007-08 and 2008-09 at Rampur

\begin{tabular}{|c|c|c|c|c|c|c|c|c|c|c|c|c|}
\hline \multirow{2}{*}{$\begin{array}{l}\text { Treat- } \\
\text { ments }\end{array}$} & \multicolumn{3}{|c|}{ Ear length $(\mathrm{cm})$} & \multicolumn{3}{|c|}{ Kernel rows/ear } & \multicolumn{3}{|c|}{ Kernels/row } & \multicolumn{3}{|c|}{1000 grain wt.(g) } \\
\hline & \begin{tabular}{|l|}
$2007-08$ \\
\end{tabular} & 2008-09 & Mean & 2007-08 & 2008-09 & Mean & 2007-08 & 2008-09 & Mean & 2007-08 & 2008-09 & Mean \\
\hline T1 & 9.5 & 11.3 & 10.4 & 12.2 & 13.2 & 12.7 & 22.4 & 26.8 & 24.6 & 404.8 & 353.4 & 379.1 \\
\hline $\mathrm{T} 2$ & 12.4 & 13.8 & 13.1 & 13.4 & 13.4 & 13.4 & 29.8 & 28.6 & 29.2 & 480.6 & 437.6 & 459.1 \\
\hline $\mathrm{T} 4$ & 11.2 & 12.4 & 11.8 & 11.8 & 13.7 & 12.7 & 26.2 & 26.8 & 26.5 & 444.6 & 434.4 & 439.5 \\
\hline T5 & 13.3 & 12.4 & 12.8 & 14.6 & 14.0 & 14.3 & 29.3 & 27.5 & 28.4 & 479.8 & 445.3 & 462.5 \\
\hline T6 & 11.2 & 12.9 & 12.0 & 13.6 & 13.0 & 13.3 & 24.5 & 27.4 & 25.9 & 457.2 & 406.8 & 432.0 \\
\hline$\overline{\text { F-test }}$ & * & $* *$ & & NS & NS & & * & NS & & * & * & \\
\hline $\mathrm{CV} \%$ & 5.2 & 4.98 & & 11.2 & 5.08 & & 4.4 & 6.17 & & 13.8 & 6.72 & \\
\hline $\operatorname{LSD}(0.05)$ & 1.20 & 1.13 & & & - & & 6.4 & - & & 46.8 & 51.01 & \\
\hline
\end{tabular}

NS, $\mathrm{p}>0.05 ;{ }^{*}, \mathrm{p}<0.05 ; * *, \mathrm{p}>0.01$ 
Table 3: Effects of Azotobacter on stover and grain yield of maize during 2007-08 and 2008-09 at Rampur

\begin{tabular}{|c|c|c|c|c|c|c|c|}
\hline \multirow{2}{*}{ Treatments } & \multicolumn{3}{|c|}{ Stover yield ( $\left.\mathrm{tha}^{-1}\right)$} & \multicolumn{3}{|c|}{ Grain Yield $\left(t h^{-1}\right)$} & \multirow{2}{*}{$\begin{array}{l}\text { Grain yield increase (\%) by } \\
\text { inoculation over non-inoculation }\end{array}$} \\
\hline & 2007-08 & 2008-09 & Mean & 2007-08 & 2008-09 & Mean & \\
\hline$\overline{\mathrm{T} 1}$ & 2.80 & 4.86 & 3.83 & 2.75 & 2.91 & 2.83 & - \\
\hline $\mathrm{T} 2$ & 9.28 & 10.05 & 9.67 & 5.40 & 6.30 & 5.85 & - \\
\hline T3 & 5.45 & 7.32 & 6.39 & 3.27 & 4.39 & 3.83 & 35 \\
\hline $\mathrm{T} 4$ & 5.80 & 7.48 & 6.64 & 3.12 & 4.49 & 3.81 & 34 \\
\hline $\mathrm{T} 5$ & 7.90 & 6.03 & 6.97 & 4.90 & 4.62 & 4.76 & 15 \\
\hline $\mathrm{T} 6$ & 6.10 & 6.77 & 6.44 & 4.22 & 4.06 & 4.14 & - \\
\hline $\mathrm{T} 7$ & 9.46 & 10.63 & 10.05 & 5.36 & 6.38 & 5.87 & 0.3 \\
\hline $\mathrm{T} 8$ & 12.8 & 11.04 & 11.92 & 6.22 & 6.62 & 6.42 & \\
\hline$\overline{\text { F-test }}$ & ** & $* *$ & & $* *$ & $* *$ & & \\
\hline $\mathrm{CV} \%$ & 13.1 & 15.46 & & 12.8 & 15.47 & & \\
\hline $\operatorname{LSD}(0.05)$ & 1.99 & 2.18 & & 1.23 & 1.31 & & \\
\hline
\end{tabular}

NS, $p>0.05 ;{ }^{*}, p<0.05 ; * *, p>0.01$ 